\title{
自動車の燃料消費率の推移とその要因
}

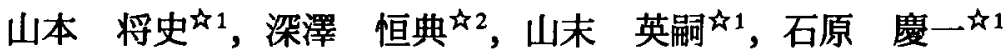 \\ 41 京都大学大学院エネルキー科学研究科エネルギー社会・環境科学専攻, † 606-8501 京都市左京区吉田本町. \\ 山2 京都大学大学院エネルキー科学研究科エネルギー社会・環境科学専攻, $=$ 606-8501 京都市左京区吉田本町, \\ [現]いすブ自動車侏)，テ210-8524川崎市川崎区殿町 3-25-1。
}

\section{The Transition of Fuel Economy on Automobiles and its Factor}

\author{
Masashi Yamamoto ${ }^{\text {1 }}$, Tunenori Hukasawa ${ }^{\text {t2 }}$, Eiji Yamasue ${ }^{\text {tr }}$ and Keiichi N Ishihara 1 \\ ฟ12Department of Socio Environmental Energy Science, Graduate School of Energy Science, Kyoto University, Yosidahonmachi Sakyo-ku, \\ Kyoto 606-8501. \\ ${ }^{2}$ Department of Socio Environmental Energy Science, Graduate School of Energy Science, Kyoto University, Yosidahonmachi Sakyo-ku, \\ Kyoto 606-8501. [Isuzu Motors Limited, 3-25-1 Tonomachi Kawasaki-ku, Kawasaki 210-8524].
}

Received January 16, 2002

\section{SYNOPSIS}

The fuel economies for various kinds of automobiles have been investigated. According to the fuel economy based upon the department of transportation standard, the fuel economies in 2000 improved $9 \sim 23 \%$ compared to those in 1990 for each class of the curb weight. However, the total fuel economy in Japan, which were estimated from the both data of the total amount of fuel consumption and total killometrage in Japan from 1965 to 2000, show about $9 \mathrm{~km} / \mathrm{liter}$, and in the recent decade it became rather worse. The reason for this inconsistency is that the large size automobile became popular because of the inclination of user, anti-regulation of automobile tax, price down of fuel and so on. In order to improve the total fuel economy aiming the reduction of $\mathrm{CO}_{2}$ emission, two problems, which are "improvement of the fuel economy for the respective automobile" and "suppression of the over sizing of automobile", are examined.

KEYWORDS

fuel economy, automobile

\section{1 緒 言}

1960年代後半から 1970 年の高度成長期にかけ $3 C$ (カー, カ ラーテレビ,クーラー)と呼ばれ,憧れの的であった自動車は, 日本経済の発展・成熟を経て現在では生活必需品となってい る.しかし，自動車は生活を快適・便利なものにする一方，年 間一万人を越える交通事故死亡者，排気ガスによる地域大気 環境の污染，振動や騒音，公共交通機関の衰退など様々な弊 害も生み出してきた。また地球罢境に与える影響も決して小 さなものではなく,乗用車による二酸化炭素の排出量は1998年 において年間約6000万 $\mathrm{t}-\mathrm{C}^{1)}$ であり，日本における二酸化炭素 排出量の二割以上を占めているのが現状である.日本の二酸 化炭素排出量のうち運輸部門からの排出が占める割合は年々 大きくなっているが，これは運輸部門エネルギー消費量の約 九割を占める自動車の, 走行距離が大きく増大していること が原因である.Fig.1に日本における二酸化炭素総排出量の推 移と自動車の総走行距離の推移を示すが2)，1970 年には総走 行距離が 2730 億 $\mathrm{km}$ であったのに対し 1999 年には 7651 億 $\mathrm{km}$
と2.8倍もの増加加見られる.このことは, 単純には自動車の ガソリン消費量すなわち二酸化炭素排出量が約 3 倍になった ことを意味している。このことから，自動車による二酸化炭 素排出量を削隇することが，地球罢境問題の解決策の一つで あることが分かる。

そのような状況の中で, 1997年にCOP3 (気候変動枠組条約 第3回締約国会議)で探択された京都議定書により，日本は温 室効果ガス排出量を 2008 年〜 2013 年平均で 1990 年比 $6 \%$ 削 隇する目標が定められた.これを受けて政府は「地球温暖化 对策推進大綱」を定め, 各分野での削減目標を設定した². 運 輸部門では排出量の增加を考虑し，エネルギー消費量を 1995 年水準と同水準に抑えることが目標とされた。具体的には 2010 年時点において 1730 万 kl (原油換算) の消費量削減が求 められている．その中で「自動車燃費の改善」によるエネル ギー削減量は 450 万 kl (原油換算)となっており,これは運輸 部門全体の削減目標の4分の1に相当し, 自動車の燃費改善に 対する期待が大きいことを意味している．また，これと平行 


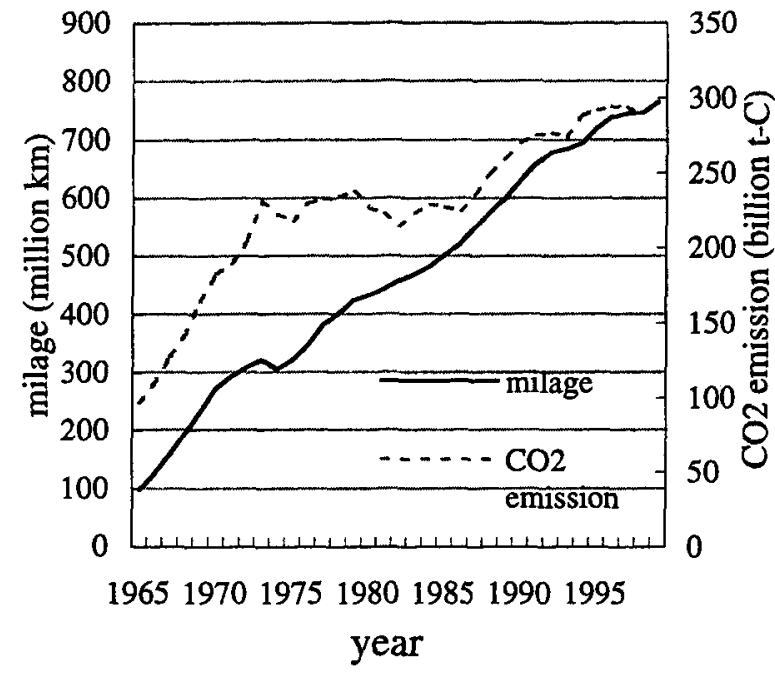

Fig.1 The transition of milage and $\mathrm{CO}_{2}$ emission.

して 1999 年 4 月に省エネルギー法が改正され，自動車におい てトップランナー方式による省エネルギ一策が進められるこ ととなった。

各自動車メーカーにおいて燃費向上の努力は特に近年精力 的になされており，エンジンとモーターのハイブリッド化， 筒内直接噴射エンジン4), リーンバーンエンジンなどが開発さ れている.メーカーの公表值によると，筒内直接噴射エンジ ンで25〜35\%，リーンバーンエンジンで約 20\% 程度の燃費向 上が実現されている.また，その他にもエンジン効率の向上， 車重の軽量化，空気抵抗の削減などの技術が導入されており， 近年の $10 \cdot 15$ モード燃費值は飛躍的に向上している.ところ が実際に燃費のデータを広い車種や年式に渡って調查し，紷 合的な研究が行われた例は皆無といえる.そこで本研究では， 各種統計資料,インターネット，自動車関連雑誌，アンケート を基に $10 \cdot 15$ モード燃費だけでなく実測燃費も調查し，現状 の社会における自動車燃費についてその要因を分析し，二酸 化炭素排出量削隇の方策について検討することを目的とする.

\section{2 自勳車の実測燃貫の調查}

\section{$2.110 \cdot 15$ モード燃費テータの収集およびその結果}

10・15 モ一ド燃費とは，市街地走行を想定した 10 モード走 行と高速道路やバイパスなどの走行を想定した15モードとの 組み合わせにより测定される運輸省基準による燃費である. メーカーの作成するカタログにはほぼこのモードに基つく燃 費が記載されている. 本研究では，1990年に発刊された自動 車ガイドブックらおよび 2000 年に発刊された自動車ガイド ブックのに記載されている燃費を比較した。具体的には, 2010 年度の燃費基準において示された重量区分に合わせ，各文献 に記載されている燃費データを $703 \mathrm{~kg}$ 末満, $703 \sim 828 \mathrm{~kg}, 828$ $\sim 1016 \mathrm{~kg}, 1016 \sim 1266 \mathrm{~kg}, 1266 \sim 1516 \mathrm{~kg}, 1516 \sim 1766 \mathrm{~kg}$, お よび $1766 \mathrm{~kg}$ 以上，の区分毎に収集しそれらの平均值を算出し た.なお 1990 年当時は 10 モード燃費の計測しか行われてい

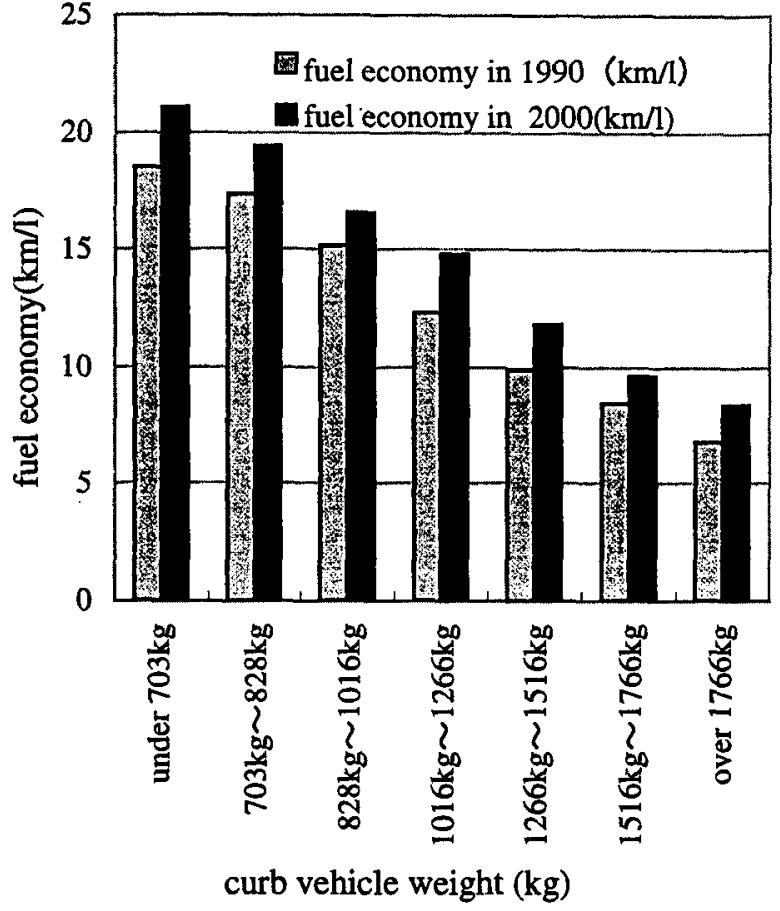

Fig.2 The comparison of fuel economy in 1990, 2000 (classified by curb vehicle weight).

Table 1 The comparison of fuel economy and curb vehicle weight in 1990, 2000 (classified by engine size).

\begin{tabular}{|c|c|c|c|c|}
\hline \multirow{2}{*}{ engine size } & \multicolumn{2}{|c|}{ weight $(\mathrm{kg})$} & \multicolumn{2}{c|}{ Fuel economy $(\mathrm{km} / \mathrm{l})$} \\
\cline { 2 - 5 } & 1990 & 2000 & 1990 & 2000 \\
\hline $660 \mathrm{cc}$ & 654.17 & 837.98 & 18.38 & 17.85 \\
\hline $1500 \mathrm{cc}$ & 985.74 & 1118.33 & 15.09 & 16.02 \\
\hline $1600 \mathrm{cc}$ & 1072.13 & 1132.31 & 12.99 & 13.88 \\
\hline $2000 \mathrm{cc}$ & 1332.78 & 1379.88 & 10.22 & 12.10 \\
\hline $2500 \mathrm{cc}$ & 1575.45 & 1535.26 & 8.95 & 9.89 \\
\hline $3000 \mathrm{cc}$ & 1577.89 & 1662.20 & 8.40 & 9.46 \\
\hline
\end{tabular}

なかったので，10・15 モード燃費に変換して比較した．調査 結果を Fig.2に示すが，全ての重量区分において 2000 年の燃 費データが 1990 年の燃費テータに勝っており, 9〜23\%向上 している.

またTable 1には，上記の文献值を排気量毎に整理した值を 示す. 表から分かるように，同排気量の場合 1990 年の車両重 量より 2000 年の車両重量の方が $2500 \mathrm{cc}$ クラスを除き重く なっている.それにもかかわらず軽自動車以外で燃費が向上 しているのは，エンジン技術の向上が大きな効果を上げたた めと考えられる.また，これらの結果から，同重量区分にお ける比較では2000年の方が小排気量車の占める割合が多いと 考えられ，これが見かけ上燃費向上に大きな役割を演じたと 考えられる．軽自動車の燃費が悪化しているのは，近年の車 にはエアコン装置, パワーステアリング, パワーウィンドウ, オーティオ機器など様々な機能が搭載されているか，これら の動力は全てエンジンの馬力から賄われている.軽自動車は 
排気量が小さいため馬力も小さく，エンジンの効率向上より も上記の機能によって奪われた馬力の分燃費が悪化したと考 えられる。

以上の結果から，最近の 10 年間においても，技術者の努力 により車一台毎の燃費は軽自動車の場合を除いて同重量区分， 同排気量区分において向上していることが分かった.しかし， これらの值は車一台毎の $10 \cdot 15$ モード然費テータであり車の 車両台数などは考虑されていないため, 日本全国レベルでの 燃費の推移を読みとることができない，国土交通省ではこれ らに台数を掛け合わせた平均燃費を算出しているが, $10 ・ 15$ モード燃費であるため実燃費との乘離がある，そこで，次に 日本における総走行距離および総燃料消費量からの実際の平 均燃費の算出を試みた。

2.2 日本における総走行距離および総燃料消費量からの燃費 テータ算出

日本における自家用乗用車の総走行距離および総燃料消費 量は省エネルギー総覧》及び自動車輸送統計年報のよりテータ を収集し，值を算出した。このようにして得られた日本にお ける平均燃費の推移を Fig.3に示す．図より平均燃費は 35 年 間 $9 \mathrm{~km} /$ 前後と变化がなく, 最近の十数年に限って見てみる と悪化の傾向を示している．前節で述べたように，個々の車 両については然費が向上しているにもかかわらず平均燃費が 向上していない。

\section{3 日本における燃費推移に関する考察}

最近十数年の燃費悪化原因として，自動車の大型化が第一 に考えられる. Fig.4に乗用車種別毎の保有台数の移り変わり9 を示す. 図から分かるように, 1980 年代後半から急速に普通 乗用車，いわる3ナンバー車の保有台数が増えていること がわかる.3ナンバー車は車重も排気量も大きく，その結果燃 費も悪化する．個々の自動車の燃費が向上したとしても，日 本全体に渡って 3ナンバ一車の保有台数が增えれば当然日本 における平均燃費は德化する。したがって，排気量の大きな

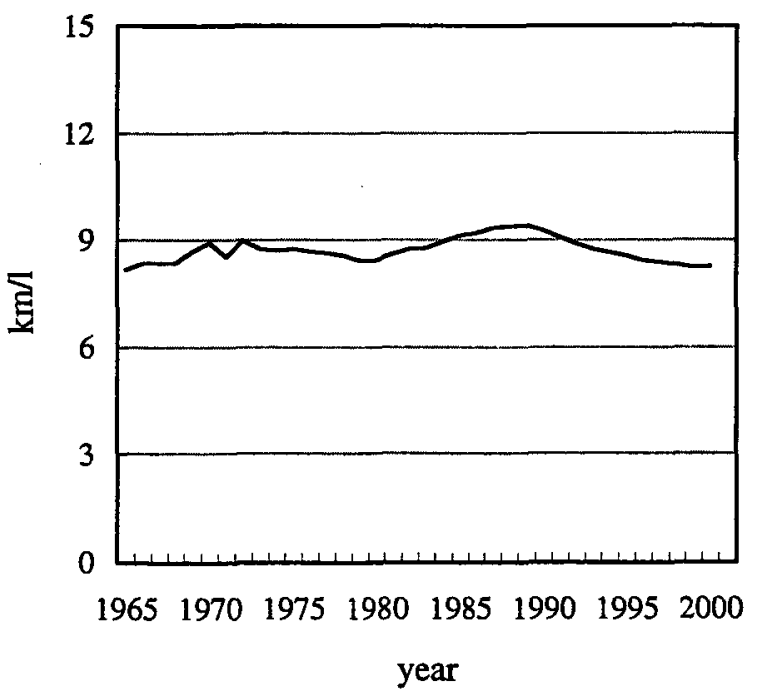

Fig.3 The total fuel economy.
な車に乗り換えずに同じサイスの車に乗り換えていたなら燃 費は改善されていたと考えられる。

自動車の大型化が進んだ原因は二つ考えられる.一つ目は ユーザーの啫好によるものである. 自動車を購入する際どの ような項目を重視するかについてのアンケート調查結果を示 す $(\text { Table } 2)^{19}$. この結果からかかるように, 自動車購入の際, 燃費を重視すると答えたのはわずか4\%にすきず,一番重視さ れるのは価格である．普通乗用車は小型乗用車に比へて価格 が高く,このことは乗用車の大型化とは逆の結果をもたらす ように思える.しかし1989年に自動車税の改正が行われ，普 通乗用車の自動車税が大幅に隇税されたことにより普通乗用 車の維持コストが低下したことを考虑すると，普通乗用車の 保有促進につながったと考えられる.またそれと共に消費税 導入に伴う物品税の廃止により，排気量の大きな自動車の值 段が下がり手ころ感が高まったことも普及を後押しした理由 の一つといえる. 二つ目はガソリン価格の低下によるもので ある.Fig.5にガソリン価格の推移を示す ${ }^{11)}$.この図から, 1990 年以降ちょうど普通乗用車の保有台数增加の時期と重なるよ うにガソリン価格が低下することが見て取れる。がソリン価 格の低下によりユーザーの燃費に対する関心が低くなり，こ れが燃費の悪い大型車の購入の障壁を下げることにつながっ ていると考えられる。

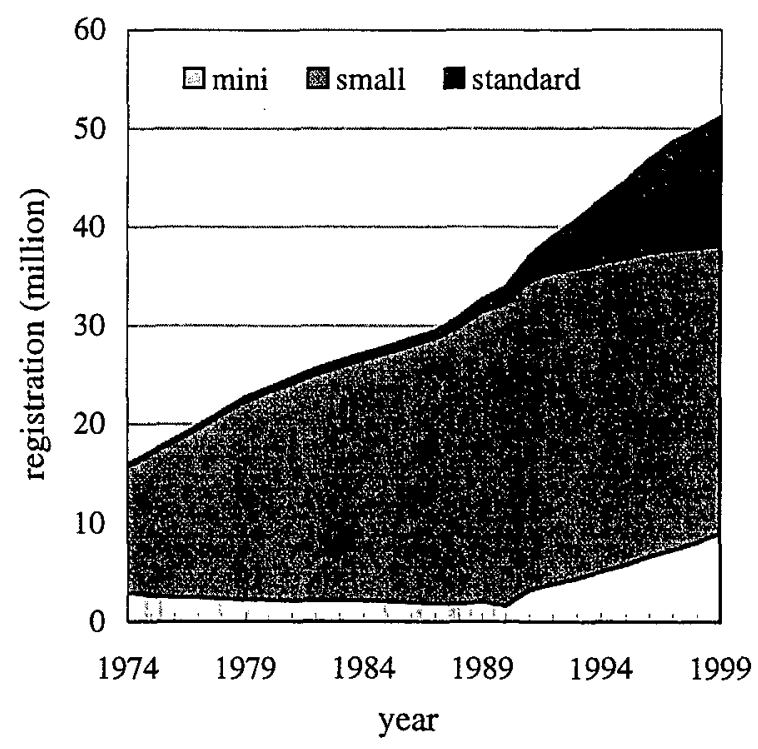

Fig.4 The registration of passenger car.

Table 2 The most important factor on choosing car.

\begin{tabular}{|c|c|}
\hline point & ratio \\
\hline price & $33 \%$ \\
\hline design & $20 \%$ \\
\hline brand-name & $12 \%$ \\
\hline safety & $9 \%$ \\
\hline easy drive & $6 \%$ \\
\hline cab space & $4 \%$ \\
\hline fuel economy & $4 \%$ \\
\hline others & $12 \%$ \\
\hline
\end{tabular}




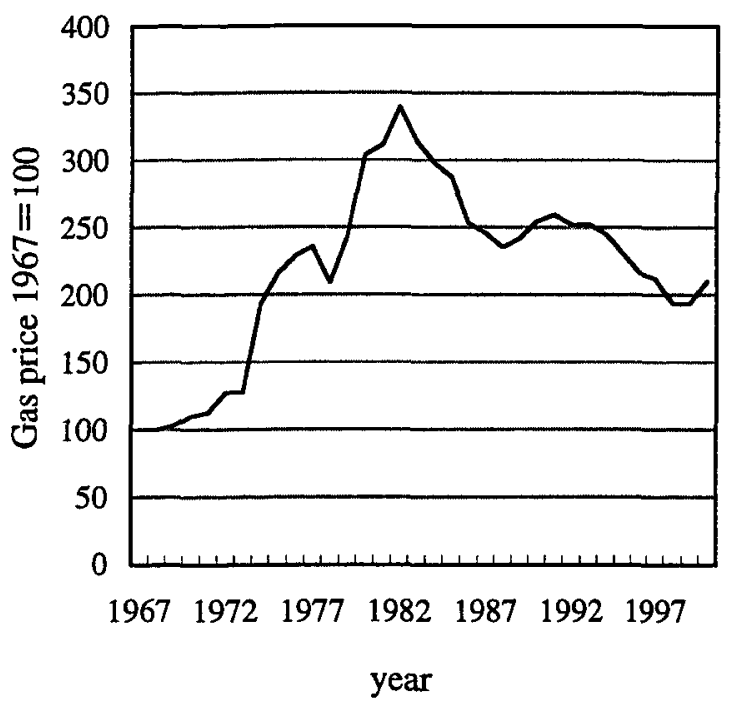

Fig.5 The transition of gas price.

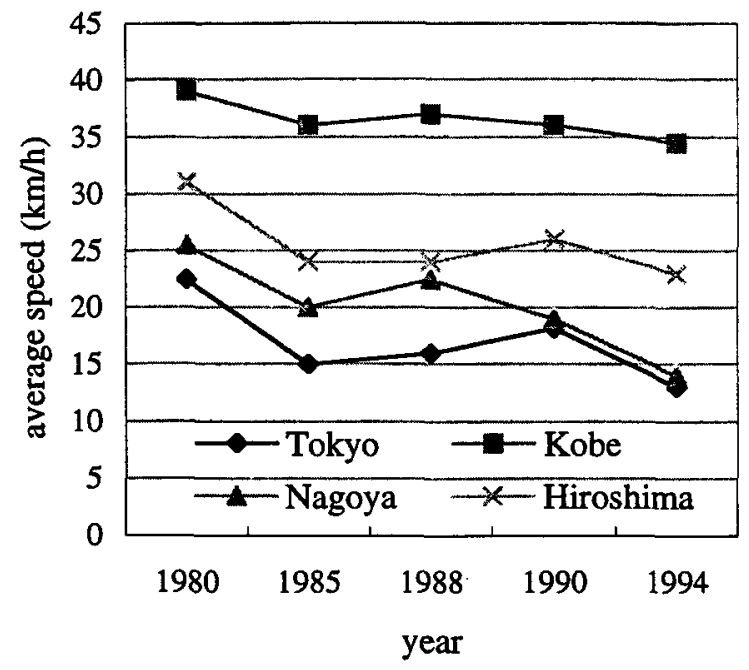

Fig.6 The average speed on some city.

この他にも，平均実測燃費の悪化した原因として踖滞量が

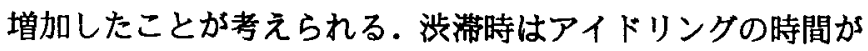
多くなることや加速減速の回数加增加するため燃費が悪化す る. 実際平均速度が $40 \mathrm{~km} / \mathrm{h}$ から $10 \mathrm{~km} / \mathrm{h}$ 一変化すると燃費は 50\%悪化する ${ }^{12)}$ と言われている. Fig.6に各都市の渋滞ピーク 時における平均速度の推移を示す. 四加らわかるよう，平 均速度は一時的に改善されることもあったが長期的には悪化 しており，1994年の值が最も平均速度が低い。このことより， 湤滞量の増加が平均燃費の悪化の原因の一つと考えることは 妥当といえる.

以上より, 自動車個々の燃費はメーカーの努力により確実 に向上しているが, 購入者の啫好や浩滞の増加といった社会 的な理由により，日本全体としての平均燃費が悪化している ことが分かった。

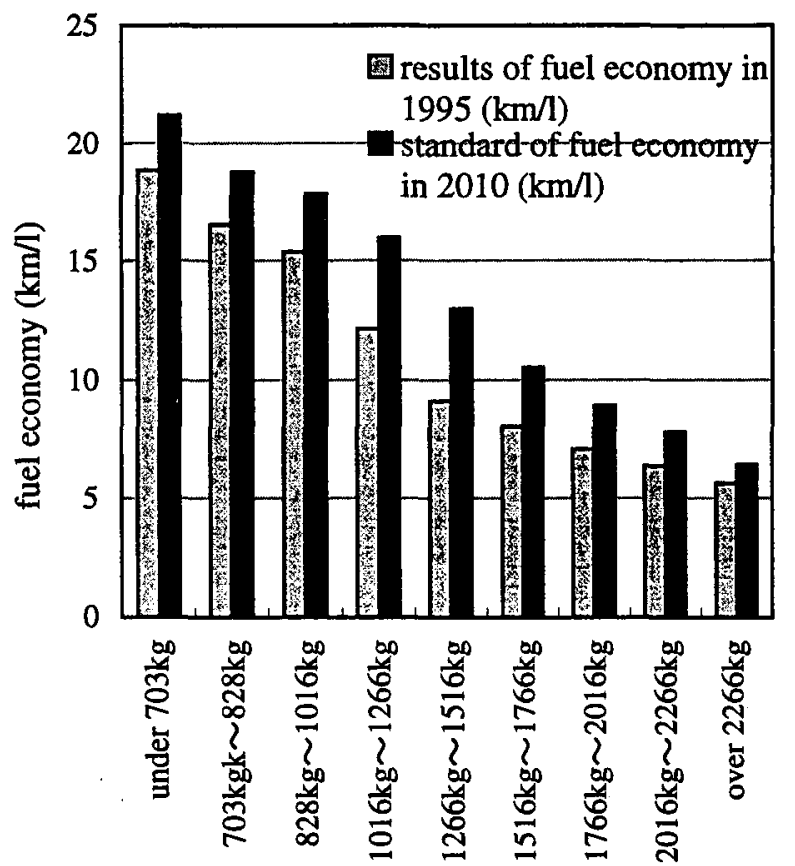

curb vehicle weight $(\mathrm{kg})$

Fig.7 The fuel economy standard and results.

\section{3 平均燃費改善人の提言}

緒言でも述べたように, 2010年度の燃費基準值は二酸化炭 素排出量の削減を目標として定められたものである.それを 受けて各自動車メーカーは然費基準值達成のための技術開発 を行い, 自動車個々については燃費の改善に成功している. しかしながら，平均燃費は 3 ナンバー車保有台数の増加など により悪化した.このままでは燃費基準が達成されても，本 来の目的である二酸化炭素の削減には効果がない。そこで平 均燃費改善に対し二つの方策について検討を行う。一つは自 動車個々の燃費をさらに向上すること，一つは自動車の大排 気量化に歯止めをかけることである.

3.1 自動車個々の燃費の改善に伴う問題点

自動車個々の燃費改善に向けてはこれまでにも述べてきた ように 2010 年燃費基準達成にむけて努力がなされている. Fig.7に重量区分ことの目標と1995年度実續值を示す. 区分こ とで要求される改善率に差があるが最低でも $11 \%$, 最も高い ところでは $30 \%$ の向上が要求される.一方, 燃費改善技術と して可変バルフタイミング, 電子制御燃料噴射装置, 燃焼室 改良などの数々の技術が開発中であり，粉末治金技術もその 技術改良に寄与している.しかし简内直接噴射エンジン(直噴 エンジン)を除く燃費向上技術による改善は10数\%にとどま ると考えられており ${ }^{13)}$, 目標值達成のためには直噴エンジン 搭載もしくはハイブリッド化なども必要になってくると考え られる。だが直噴エンジンは 10.15 モード燃費と実燃費との 乘離が大きいという問題が存在する。

Table 3に本研究において調查した自動車の実燃費データを 
示す. 調查はインターネット (約 1600 件), 自動車関連雑誌 (約 300件)および本研究室において作成したホームページで のアンケート調查 (約 50 件)に基づいている.この結果によ り, 実燃費は運輸省審查值の約 $80 \%$, 直噴エンジン(直噴エン ジン)搭載車に限ってみれば約 $60 \%$ との結果が得られた。直 噴エンジン搭載車の実際の败費がのびない原因として審査值 測定時と実走行時の環境の違いが考えられる．直噴エンジン は低回転数時に薄い空燃比(希薄然焼モード)でエンジンを使 用することにより燃費向上をねらったものである。しかし， 強い加速を求めるときや高速巡航時には通常燃焼モードに切 り替わる.審查值測定時には最大加速が求められる場面でも, 希薄燃焼モードで対応でき通常モードに切り替わることはな い.一方, 実走行時には高回転での使用が多くなり希薄燃焼 モードを使用する事が少なく直噴エンジンの特性を生かすこ とができない.このような理由により，直噴エンジン搭載車 では 10・15 モード败費と実燃費との乘離が進んたもものと考え られる. 同じくハイブリッド車についても実際の燃費は運輸 省審查值の約 60\%にとどまっている.

以上から今後直噴エンジン搭載車の普及により2010年度の 然費基準値が達成されても実際の燃費は改善せず二酸化炭素 排出量の㸝減につながらない恐れがある.

3.2 自動車の小排気量化

最初に車の小排気量化に成功したアメリカの例を示す.ア メリカでは 1975 年に成立したエネルギー政策および保護法 (Energy Policy and Conservation Act)の下で, 自動車メーカー の生産する乗用車燃費平均の改善を規定した企業平均燃費 (CAFE值: Corporate Average Fuel Economy) 規制が実施されて いる. CAFE値は以下の式により算出される。

\section{CAFE 值 $=(\Sigma$ 当該形式の撚費 $\times$ 販売台数 $) / \Sigma$ 販売台数}

1974 年の CAFE 值が 14.2 MPG (Mile Per Gallon)であること を考えると，1985年の規制值 $(27.5 \mathrm{MPG})$ は，乗用車の燃費を 約 2 倍に向上することを要求するものであり，さらに，末達

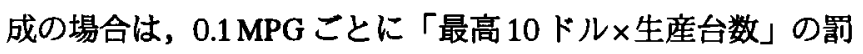
金をメーカーが納めなければならないという厳しいもので
あった.上式からもわかるように, CAFE值は個々の車の燃費 変化だけでなく，売れる車の種類によっても変わってくる. 例えば燃費の良い小型車が多く売れると CAFE值は改善され るが，その反対に然費の悪い大型車が多く売れるとCAFE值 は悪化する. それを襄付けるかのようにCAFE值と平均排気 量の推移を見ると, 平均排気量が急激に低下するのと平行し

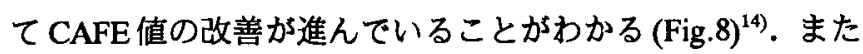
1983 年にCAFE值が低下したのも，ガソリン価格の低下によ り大型車の売れ行きが急激に伸びたことによるものである ${ }^{15)}$. このように CAFE值の改善に成功した結果, 実際の燃費も大 きく改善し1990年代半ばには日本を上回る水準にまで燃費は 向上した(Fig.9 $)^{19}$.以上のようにアメリカにおいては自動車の 小型化を進めることで燃費の大幅な改善に成功した。

日本においては1979年に「エネルギーの使用の合理化に関 する法律」が規定され，それに基づき乗用車の燃費改善を図 ることが目標とされ重量別に燃費目標が定められた。重量別 の燃費基準をもうけた理由は，その当時小型車が主流を占め ておりサイスダウンによる燃費向上は困難との判断からで あったわ。しかし現在状況は大きく変化している.1989年の

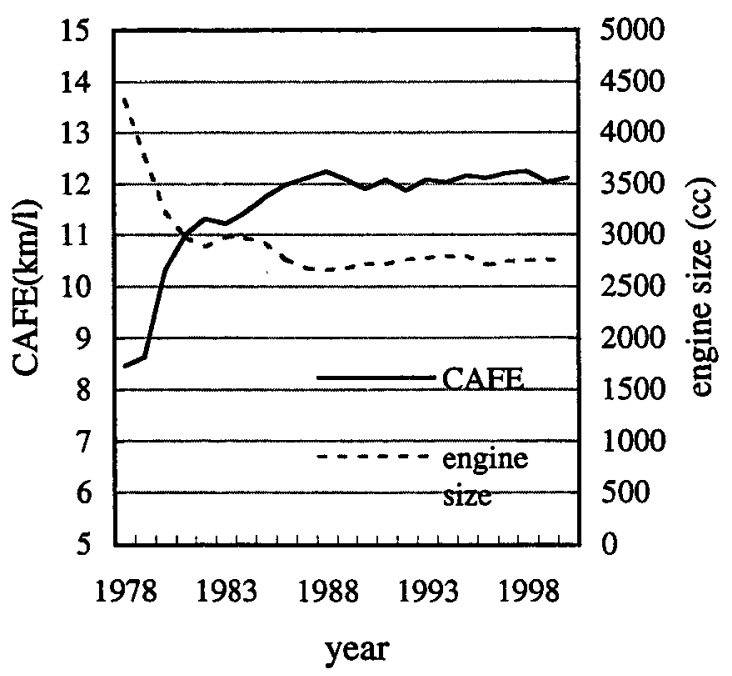

Fig.8 The transition of CAFE and engine size.

Table 3 The gap between fuel economies, actual and 10-15 mode.

\begin{tabular}{|c|c|c|c|c|c|c|}
\hline & NA & TURBO & DIRECT & ROTARY & HIBRID & AVE \\
\hline under 703kg & 0.82 & 0.48 & nq & nq & nq & 0.81 \\
\hline $703 \mathrm{kgk} \sim 828 \mathrm{~kg}$ & 0.82 & 0.74 & $\mathrm{nq}$ & $\mathrm{nq}$ & $\mathrm{nq}$ & 0.8 \\
\hline $828 \mathrm{~kg} \sim 1016 \mathrm{~kg}$ & 0.74 & 0.68 & 0.73 & $\mathrm{nq}$ & $\mathrm{nq}$ & 0.73 \\
\hline $1016 \mathrm{~kg} \sim 1266 \mathrm{~kg}$ & 0.82 & 0.77 & 0.61 & 0.76 & 0.63 & 0.79 \\
\hline $1266 \mathrm{~kg} \sim 1516 \mathrm{~kg}$ & 0.77 & 0.71 & 0.6 & 0.68 & $\mathrm{nq}$ & 0.72 \\
\hline $1516 \mathrm{~kg} \sim 1766 \mathrm{~kg}$ & 0.79 & 0.77 & 0.6 & $\mathrm{nq}$ & $\mathrm{nq}$ & 0.78 \\
\hline $1766 \mathrm{~kg} \sim 2016 \mathrm{~kg}$ & 0.83 & 0.89 & 0.6 & $\mathrm{nq}$ & $\mathrm{nq}$ & 0.81 \\
\hline $2016 \mathrm{~kg} \sim 2266 \mathrm{~kg}$ & 0.91 & 0.92 & 0.56 & $\mathrm{nq}$ & $\mathrm{nq}$ & 0.86 \\
\hline over 2266kg & 0.86 & $\mathrm{nq}$ & $\mathrm{nq}$ & $\mathrm{nq}$ & $\mathrm{nq}$ & 0.86 \\
\hline AVE & 0.8 & 0.73 & 0.61 & 0.74 & 0.63 & 0.77 \\
\hline
\end{tabular}




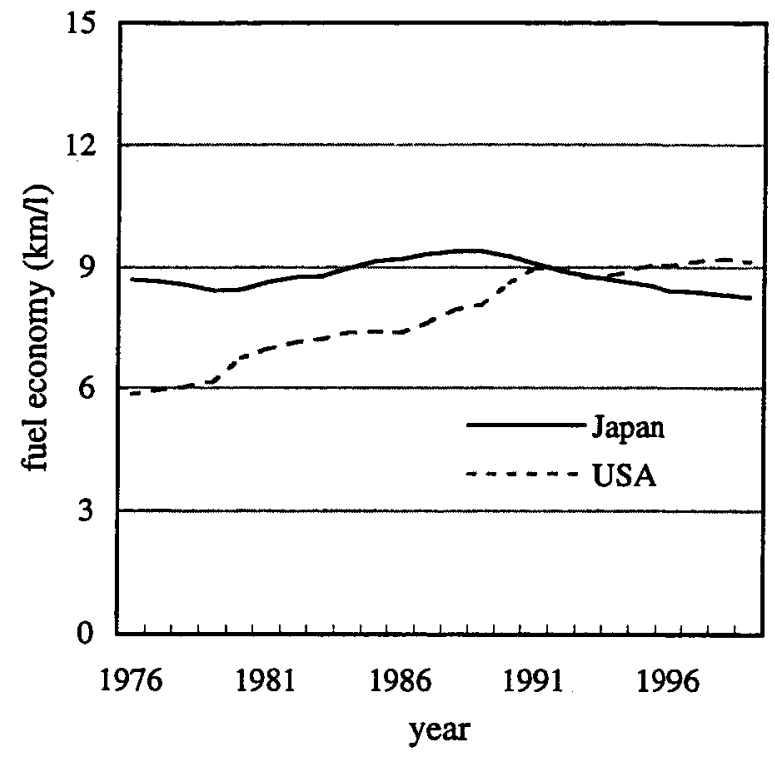

Fig.9 The comparison of fuel economy in U.S.A and Japan.

法改正を受け，選べる自動車の幅は大きく広がった．法改正 以前は排気量が $1000 \mathrm{cc} \sim 2000 \mathrm{cc}$ の車で車種のほほ九割を占 めていたのが改正後は約五割までに低下した ${ }^{1819}$. 同時に軽自 動車や $2000 \mathrm{cc}$ を越える普通乗用車の車種数加增加し, ユー ザーの選択の愊が広まり，それと平行して軽自動車や普通乗 用車の保有率增加が進んでいる.このような状況を考虑する と，現在ではサイズダウンにより然費の改善を図ることも考 えてもいいのではないだろうか. 実際サイスアップによって 平均実測燃費がどれくらい変化したか試算をおこなってみる. 想定した条件は1990年時点での排気量別乗用車保有台数割合 が 2000 年まで変化しない，すなわち 1990 年から 2000 年まで の間に車を乗り換えるときは所有していた車と同じ排気量の 車に乗るという条件である. なお保有台数の增加分について も排気量別乗用車保有台数割合に基づき増加すると考える. このようにして得られた仮想の排気量別乗用車保有台数，自 動車ガイドブックより算出した排気量別燃費，一台あたりの 走行距離から乗用車のガソリン消費量予測を行い, 2000 年の 実際のガソリン消費量と比較することで然費の算出を行った. その結果, サイスアップにより平均実測燃費は $10 \%$ 悪化した との結果が得られた。この先どの程度サイスアップが続くの かわからないが，このままでは重量区分ことでの目標值が達 成されても実測燃費との乘離の問題と共にサイズアップに伴 う平均燃費の悪化により，第一の目標である二酸化炭素排出 量の削減か難しくなる公算が大きい．このような事態を防ぐ ためにも，車各々の燃費改善たけでなくサイズダウンによる 燃費改善の方法を考えるべきである。

\section{4 結 論}

自動車，特に乗用車の燃費について，実走行燃費と $10 \cdot 15$ モード燃費の比較検討, 排気量, 重量, 保有台数からの検討,
及び米国との比較など，様々な面から検討を行った。その結 果，以下のことがわかった。

・ 自動車個々の燃費に関しては改善されている.

- 自動車個々の然費は改善されているが平均燃費は悪化して いる.

・ $10 \cdot 15$ モード燃費と実燃費の乘離の問題から自動車個々の 燃費改善には限界がある。

以上から, 二酸化炭素排出量削減のためには小排気量車へ の変換促進による燃費の改善が必要ではないかとの結論に 至った.

謝辞

本研究は日本学術振興会未来開拓学術研究推進事業におけ るプロジェクト「環境負荷低減を目的とした新しい自律分散 型都市エネルギーシステム」(プロジェクト番号: JSPS-RFTF 97P01002)の一環として行われました.ここに感謝の意を表し ます.

\section{文献}

1) (株)日刊自動車新聞社: 自動車産業ハンドブク 2001 年版, (株)日刊自動車新聞社 (2000) より算出.

2) (財)日本エネルギー経済研究所エネルギー計量分析セン ター: EDMCエネルギー・経済統計要覧，(財)省エネル ギーセンター, (2000).

3) (株)日刊自動車新聞社: 自動車産業ハンドブック 2001 年版, (株)日刊自動車新聞社, (2000)404.

4) 久米建夫, 棚田浩, 飯田和正, 村上信明, 安東弘光: " 筒内 噴射ガソリンエンジンのための燃焼制御 ", http://www. mitsubishi-motors.co.jp/NEWS/gdi-engine/gdi00.html.

5)社団法人自動車工業振興会: 自動車ガイドブックvol.37, 社 団法人自動車工業振興会, (1990).

の) 社団法人自動車工業振興会: 自動車ガイドブックvol.47, 社 団法人自動車工業振興会, (2000).

7) 資源エネルギー庁省エネルギー石油代替エネルキー対策 課 : 省エネルギー総覧 1997, 通産資料調查会,(1996).

8) 運輸省運輸政策局情報管理部統計課: 自動車輸送統計年報, 運輸政策局情報管理部。

9）(株)日刊自動車新聞社: 自動車産業ハンドブック2001 年版, (株)日刊自動車新聞社, (2000)388-389.

10) 坂口隆洋: "低燃費自動車の普及が自家用乗用車のガソリ ン需要に及ぼす影響", エネルギー経済, 26(4)(2000)1-22.

11）総務庁統計局: 消費者物価指数年報, 日本統計協会.

12) 運輸省: 運輸白書平成 11 年度版, 大藏省印刷局, (2000)91.

13）総合エネルギー調査会省エネルギー基準部会自動車判断 基準小委員会・運輸技術審議会自動車部会燃費基準小委 員会中間とりまとめ, http//www.meti.go.jp/feedback/data/ iscar00j.html.

14) http://www.nhtsa.dot.gov/cars/problems/studies/fuelecon/ index.html. 
15) 中島泰夫: "乗用車の燃費低減についての諸問題(1)", 機械 の研究, 36(8)(1984)43-49.

16) Stacy C Davis, Oak Ridge National Laboratory: TRANSPORTATION ENERGY DATA BOOK EDITION21.

17) 中島泰夫: "乗用車の燃費低減についての諸問題(1)",機械
の研究, 36(8)(1984)43-49.

18) 社団法人自動車工業振興会: 自動車ガイドブクvol.37, 社 団法人自動車工業振興会, (1990).

19）社団法人自動車工業振興会: 自動車ガイドフックvol.47, 社 団法人自動車工業振興会, (2000). 